\title{
Dominika JAGIELSKA
}

CLLE-ERSS, Toulouse University

jagielskadominika@hotmail.com

\section{VERB-BASED APPROXIMATIONS IN POLISH AS A FIRST LANGUAGE: ACQUIRING AND STRUCTURING THE VERBAL LEXICON}

\section{INTRODUCTION}

When we study the mechanisms of first language acquisition, we notice that most research focuses on the noun lexicon rather than on the verbal lexicon. Nevertheless, several authors have highlighted the significance of two aspects of the verbal lexicon.

Unconventional statements - such as She undresses the wood - are the first topic of research. Duvignau $(2003,2005)$. Duvignau, Gaume and Nespoulous (2004) and Duvignau, Gardes-Tamine and Gaume (2004) have shown the relevance of unconventional statements, particularly with verbal pivot, in first language acquisition. It appears that these statements are involved in verbal lexicon acquisition. According to Winner (1978), an unconventional statement is considered an error, a metaphor or an over-extension. This is a common classification in literature.

Literature also deals with generic verbs. Noyau (2008), Viberg (2002) and Bernicot (1981) have shown that a great number of generic verbs such as to make, to break and to cut are involved in the acquisition of a first language. A generic verb may be applied to several objects and contexts. For instance, to cut applies to solid objects in varied ways because it may be used with objects made of paper, wood, brick, plastic or glass. On the other hand, a specific verb cannot be extended to objects of different natures which refer to different semantic dimensions. A specific verb can comprise the object or tool of action such as to saw which contains the tool saw. Generic verbs can be used in conventional statements or in unconventional statements such as She broke tomato. 
Bowerman (2007) analyzed three generic verbs, to open, to break and to $\mathrm{cut}$ and her conclusion is that the use of this kind of verbs is inherent to the language considered. For instance, over-extensions with to open are frequent in English and French but not in Korean and even less in Japanese and Lao. Such a wide use of to open in English or French is due to the fact that the objects it applies to do not constitute a real group, they are chosen in an unpredictable way. On the contrary, a verb such as to eat is not used as an over-extension because the objects that this verb applies to constitute a real group: food. Open does not apply to the same objects in English or in Japanese and Lao that have several verbs meaning open and so apply to fewer objects. Children take a long time to learn which objects a verb applies to, especially in English and French, because these objects do not constitute a real group.

\section{CONTEXT AND AIMS}

Our aim is double: we wish to study the lexical hierarchy of verbs and to emphasize the presence of unconventional statements with verbal pivot in the acquisition of Polish as a first language.

An unconventional statement is seen as an error or a metaphor or an over-extension as we have shown above. For instance, Rozbiera drewno "She undresses the wood" would be seen as an error or a metaphor. Molino (1979) asserts that in a metaphor there is a gap between two words and between two fields. Other unconventional statements are seen as over-extensions such as Zepsuta balon "She broke the balloon". In fact, we may define the use of zepsuć "to break" as an over-extension. Indeed, the meaning of this verb is extended; it is used with unusual objects. According to Clark (2003), over-extensions appear for the purpose of communication among children but also among adults when the appropriate word is unknown or inaccessible.

A statement is defined as conventional when usage dictates the choice of words. A linguistic community establishes a norm and communication between speakers can only succeed if it respects this norm. A word is a merchant value according to Lafont (1978); it is used to exchange ideas. When a word is used differently from the conventional use, we call it an error. And yet those unconventional statements cannot be described as errors. Neither can they be called metaphors when child lexicon is involved. 
In fact, several authors, such as Winner (1978), postulate that a child is not able to produce metaphors. Sometimes those statements may be called over-extensions. We chose to call them approximations, following Duvignau (2005). This term was first suggested by Jakobson (1956) through the expression "approximate identification" and originally applies to aphasics. We deny these statements the status of error. Following Duvignau (2003) and Noyau (2008), we consider that they reveal a semantic and cognitive flexibility at work not only among speakers during the lexical development of their first language, but also among speakers acquiring their second language (which is beyond the scope of this study). Our aim is to prove that this flexibility is essential in structuring and acquiring lexical knowledge in a first language. Approximations would be among the processes involved in language acquisition, as a matter of fact, some processes considered as errors play an essential part and their lack may even be considered abnormal according to Duvignau, Gaume and Nespoulous (2004). For these authors, those statements should be considered in a positive way and not as simple errors because they reveal strategies at work among speakers who have difficulties in accessing the lexicon. In this context, verbs have only been the subject of a few studies. That is why it is significant to deal with this field. Moreover, according to Duvignau (2003), an unconventional statement with verbal pivot reflects a way of verbal organization by co-hyponymy. Chosen verbs (a great number of which would be generic verbs) are co-hyponyms of expected verbs, they share the same superordinate. This semantic relationship symbolizes semantic and cognitive flexibility. Our aim is to show that this theory of co-hyponyms applies to the Polish language.

Our analysis deals with the phenomenon of verb acquisition. We consider this acquisition through semantically close verbs which are not synonymous. We observe how the semantic proximity of verbs helps our subjects in lack of a lexicon to fill their gaps. Our hypothesis is that the participants will use a great number of generic verbs in an unconventional way.

In the first place, we will present our participants and the method used to bring to light generic verbs and unconventional statements. In the second place, we will present our statistical results. Finally, we will conduct our qualitative analysis: unconventional statements based on Polish specificities as verbal prefixes and verbal synonymy as well as unconventional statements based on generic verbs. 


\section{METHOD}

First we will present our participants, their number and their age. We will then describe the details of our experimental paradigm. Finally, we will explain how the data were coded.

\subsection{PARTICIPANTS}

We wish to reveal and demonstrate the significance of generic verbs and unconventional statements - considered as characterization of semantic and cognitive flexibility - in the Polish language. Our participants are children divided in two categories. The first group is composed of children between three and five years old who are learning Polish as a first language. The second group comprises children between six and ten years old with a more developed lexicon. Apart from this comparison between two populations, we also compare children with adults who have a stable lexicon. We may therefore compare age and acquisition level in each group. This allows us to examine how participants who have difficulties accessing the lexicon will compensate with the semantic promiscuity of verbs. We are also able to determine the proportion of generic verbs and approximations used by participants with a stable lexicon.

Here are our participants:

- 6 children in the phase of early acquisition: $3-5$ years old

- 6 children with a developed lexicon: 6-10 years old

- 12 adults

Those participants are coded as:

- Group 1: Children in the phase of early acquisition: LMP-EAP 1 to 6

- Group 2: Children with a developed lexicon: LMP-EAT 1 to 6

- Group 3: Adults: A-POL 1 to 12

In our data analysis, we will refer to participants by their code.

\subsection{EXPERIMENTAL PARADIGM: "APPROX"}

We subject our participants to an analysis protocol aimed at revealing verb-based approximations: "Approx" (Duvignau et Gaume, 2001; 2004). It consists in watching a video showing a succession of seventeen daily actions. There are three categories of action: to damage, to take off and to separate. 


\begin{tabular}{|c|c|c|}
\hline TO DAMAGE & TO TAKE OFF & TO SEPARATE \\
\hline $\begin{array}{l}\text { /to burst a balloon/ } \\
\text { /to scramble paper/ } \\
\text { /to break a glass/ } \\
\text { (with a hammer) } \\
\text { /to mash tomato/ } \\
\text { (manually) } \\
\text { /to tear up the newspaper/ }\end{array}$ & $\begin{array}{c}\text { /to peel a carrot/ } \\
\text { (with a peeler) } \\
\text { /to peel an orange/ } \\
\text { (manually) } \\
\text { /to strip the bark off a log/ } \\
\text { /to undress a doll/ } \\
\text { /to dismantle legos/ } \\
\text { /to peel a banana/ } \\
\text { (manually) }\end{array}$ & $\begin{array}{l}\text { / to crumble bread/ } \\
\text { (manually) } \\
\text { / to cut (up) bread/ } \\
\text { (with a knife) } \\
\text { /to break bread/ } \\
\text { (manually) } \\
\text { /to chop parsley/ } \\
\text { (with a knife) } \\
\text { /to saw a plank/ } \\
\text { /to unpick a shirt/ }\end{array}$ \\
\hline
\end{tabular}

Actions are chosen at random but with instruction to present the action / to burst a balloon/ last. This constraint was originally designed for Asperger and autistic participants - who are not the subject of our study - but is also appropriate here. As a matter of fact, rudeness of this action may lead to strong reactions. Indeed, several languages have been studied this way. This protocol was for example used on French and Korean participants.

This protocol suits the Polish language. Indeed, all actions and categories of action exist in Polish and may be translated into Polish. As far as the protocol is concerned, we will see below how specificities of the Polish language affect the results.

The participants performed two tasks. The first one is a denomination task with an instruction given during its accomplishment. We ask:

"What has the woman done?"

This task is followed by a task of reformulation. The video is switched off and we ask:

"Tell me in another way, with other words, what the woman has done"

We take note of every answer. In this study, we derive our results from two tasks.

\subsection{DATA CODING}

The data were coded according to the following criteria:

a. valid/invalid

b. approximation/conventional

c. generic/specific 
a. An answer is considered valid when it comprises a verb related to the target action. There are several possible valid answers. For instance, ściagać "to take off", zdejmować "to take off" and rozbierać "to undress" are all valid for the action / to undress a doll/. To the contrary, an answer is invalid when it cannot be linked with relevance to the action-target couple, such as Jest dużo kawałków "There is a lot of fragments" for the action /to break a glass/.

b. We consider that a verb is conventional when it belongs to the same lexicon-conceptual field as the noun with which it combines in the statement. Its use does not include any semantic or pragmatic equivocal and is seen as usual in the linguistic system concerned. Such is the case with kroić "to cut" for the action /to saw a plank/. Kroić "to cut" shares a great proximity with the expected verb piłować "to saw": they apply to wood, they refer to a tool and they express the idea of division.

On the opposite, an answer is considered an approximation when the use of the verb provokes a tension. Two types of tension exist:

- the first tension is extra-field and consists of the link between verb and noun. An approximation is called extra-field when there is a verb-object conflict and when two semantic fields are involved, as for instance in the use of rozbierać "to undress" for the action / to peel an orange/. As a matter of fact rozbierać "to undress" applies to human being whereas obierać "to peel" applies to food. Nevertheless, the verbs involved, rozbierać "to undress" and obierać "to peel" share a link of extra-field co-hyponymy because they share the same superordinate. That is, rozbierać "to undress" and obierać "to peel" are extra-field co-hyponyms which share the same superordinate $z$ dejmowac "to take off". Chosen verbs share a middle proximity with expected verbs.

- the second tension is intra-field and relates to the verb and the apparent reality. The chosen verb belongs to the same semantic field as the noun but does not refer to the action, such as kroic "to cut" for the action / to peel an orange/. In that case, the approximation is intra-field since only one semantic field is involved and the tension is pragmatic. Verbs involved share a link of intra-field co-hyponymy and share the same superordinate: kroić "to cut" and obierać "to peel" are intra-field co-hyponyms which share the superordinate /to take off/.

c. A verb is generic when it applies to many fields and objects like rwać "to tear up" which applies to many objects as flowers, tooth, paper, etc. On the contrary, a verb is specific when it includes in its morphology 
the tool, the result or the object it refers to. For instance, piłować "to saw" is specific because it includes pita "saw" in its morphology. A generic or specific verb may be used in a conventional statement or in an approximation. The results relating to generic verbs that we will show in this study refer to generic verbs in approximations.

In the following chapter, we will show in which proportions our participants produced these elements.

\section{QUANTITATIVE RESULTS}

In this section, we present our statistical results for the denomination tasks. In analyzing our data, we took into account the three parameters explained above (valid/invalid; generic/specific; approximation/conventional). For each parameter, calculations were done based on the answers provided for the 17 videos. These elements are as follows:

1. Valid answers compared with invalid answers.

The next elements deal with valid answers.

2. Generic verbs in comparison with specific verbs (as the calculation is done for 17 videos, generic and specific verbs are considered in their conventional and approximate use)

3. Approximations with regard to conventional answers.

In the table below, we provide the percentage for each element and compare this data according to the considered pairs (valid/invalid, gene$\mathrm{ric} /$ specific, approximation/conventional).

\begin{tabular}{|c|c|c|c|c|c|c|}
\hline Group & $\begin{array}{c}\% \\
\text { valid } \\
\text { answers }\end{array}$ & $\begin{array}{c}\% \\
\text { invalid } \\
\text { answers }\end{array}$ & $\begin{array}{c}\% \\
\text { generic } \\
\text { verbs }\end{array}$ & $\begin{array}{c}\% \\
\text { specific } \\
\text { verbs }\end{array}$ & $\begin{array}{c}\% \\
\text { approxi- } \\
\text { mations }\end{array}$ & $\begin{array}{c}\% \\
\text { conventional } \\
\text { statements }\end{array}$ \\
\hline Group 1 & $68 \%$ & $32 \%$ & $45 \%$ & $23 \%$ & $23 \%$ & $45 \%$ \\
\hline Group 2 & $92 \%$ & $8 \%$ & $53 \%$ & $39 \%$ & $20 \%$ & $72 \%$ \\
\hline Group 3 & $100 \%$ & $0 \%$ & $35 \%$ & $65 \%$ & $9 \%$ & $91 \%$ \\
\hline
\end{tabular}

The rate of valid answers is very high in each group and even absolute for group 3. Group 1 produced the lowest number of valid answers.

The percentage of generic verbs is significant in each group. Group 2 have the highest rate, which shows that children keep using such verbs 
as the lexicon fills up. In proportion, it is group 1 that used most generic verbs (two thirds of valid answers), more than group 2 (half of valid answers). Group 3 produced the lowest number of generic verbs (a third of valid answers). All groups considered, the use of generic verbs is stable. We may conclude that the use of generic verbs is high during language acquisition but also in people with a stable lexicon.

Group 1 has the lowest rate of production of specific verbs while group 3 has the highest. This is coherent with the assumption that the production of specific verbs increases as the lexicon fills up. In groups 1 and 2, the percentage of specific verbs is lower than the rate of generic verbs. On the contrary, group 3 produced more specific verbs than generic verbs. This shows a high production of generic verbs in the childish lexicon and a high production of specific verbs in the adult lexicon.

All groups made approximations. Group 1 is the first one, followed by group 2 and 3 . In proportion, the classification is identical: group 1 (one third of valid answers), group 2 (one fifth) and group 3 (less than one tenth). The lower is the level of acquisition; the higher is the number of approximations.

We will now present this data from a qualitative point of view.

\section{QUALITATIVE RESULTS}

In this chapter we will conduct a qualitative analysis. First, we will present the specificities inherent to the Polish linguistic system. We will then present our results on generic verbs in approximate use. Approximations and generic verbs are the two main elements of our study.

\subsection{POLISH SPECIFICITIES IN CONVENTIONAL AND UNCONVENTIONAL RESULTS}

Our analysis protocol suits the Polish language, but the Polish verbal system has specificities that affect our results. Indeed, the Polish language has two main particularities in comparison with other languages, such as French for instance, and this has an influence on our results. Answers by some participants reveal approximations specific to Polish and therefore impossible in other languages. There are two main specificities: verbal prefixes and verb synonymy. 


\subsubsection{VERBAL PREFIXES}

Verbal prefixes may affect the meaning of a verb. Depending on the prefix a verb can on the one hand apply to an object or not and on the other hand describe an action or not. According to Janowska and Pastuchwa (2005), verbs may in this way be preceded by different prefixes and more or less derive their meaning from it. Many results are classified as unconventional on account of verbal prefixes. The following example provides an illustration:

\section{Ex. 1. wyciagnać "to take off"}

For the action / to peel a banana/:

- Wyciagła (wyciagneła is the verb's correct form) skórę banana "She took off banana's skin." (LMP-EAT 4)

In Polish, that verb does not apply to this kind of object, which belongs to the category of food. Indeed, wyciagnać unites with other sorts of objects and even living creatures. For a child, it means "to take out something of pocket" or "to grow". Therefore, its use with the action / to peel a banana/ is unconventional but valid. As the verb conveys the main ideas of to pull, to take out and to stretch, there is a similarity between the expressed verb and the expected verb: a stretching movement, a removal. A banana skin is in fact taken off in a stretching movement. The participant used this accessible and common vocabulary instead of the expected vocabulary.

The prefix here acts upon the meaning and the sphere of application of the verb. In this case, since the answer is in the past, the verb would necessarily be preceded by a prefix. But a verb does not accept every prefix. In our example, with wy the verb is approximate while with s which is the correct form (as in ściagnać) both the verb's meaning and accomplished aspect would be conventional. In our example, the prefix wy defines the meaning of the verb and its application field and thus makes it approximate in this context.

These Polish specificities affect our participants' answers, whether conventional or not. We shall now study another example of Polish specificity: verb synonymy. 


\subsubsection{VERB SYNONYMY}

The great synonymy of some Polish verbs is worth considering. This is a specificity of the Polish language which leads to specific results that would be impossible to achieve in other languages (such as French for instance). For example, the verbs kroić and ciać are both generic and both mean "to cut" or "to sever" according to circumstances. Their differences lie in their spheres of application. As a matter of fact, it depends on the tool we use: ciać with scissors and kroić with knife. The latter was given by the participants in the action /to cut bread/. It is the conventional verb we expect.

For the action / to cut bread/:

- Kroi bagietke nożem "She cuts baguette" (LMP-EAP 3) (task of denomination)

On the other hand, ciać is not the verb we expect in this case because it does not apply in priority to the object bread - even if it is conventional in the same action:

For the action / to cut bread/:

- Przecięła bagietkę "She severed baguette" (A-POL 7) (task of reformulation)

We can see that there are two verbs that mean "to cut" but they do not strictly apply to the same fields and objects.

Furthermore, some verbs are synonymous to such an extent that we can expect both to be used with the same action. Such is the case of gnieść and miażd $\dot{z} y$, expressed in the action / to mash tomato/. Both verbs mean "to mash" in the same way. It is true that miażdzyc can extend its sense to "to grind" and that gnieść can mean "to crumple" but not within the scope of this action. In that case, they are the two conventional verbs we expect in that action. Some participants used them both like distinct verbs for the same action like A-POL 3 for instance, who chose them respectively in the task of denomination and in that of reformulation for the same action:

For the action / to mash tomato/:

- Zmiażḋyła pomidora (A-POL 3) "She mashed tomato" (task of denomination)

- Zgniotta pomidora (A-POL 3) "She mashed tomato" (task of reformulation) 
In the same way gnieść and miać both mean "to crumple" according to Słownik synonimów i antonimów, 2004, and are the verbs we expect in the action / to crumple paper/. Some participants use them both for the same action in the tasks of denomination and reformulation:

For the action / to crumple paper/:

- Zgniotła papier (A-POL 6) "She crumpled paper" (task of denomination)

- Zmięła papier (A-POL 6) "She crumpled paper" (task of reformulation)

They are on the same semantic level for this action.

It is the same for drzeć and rozrywać, both used with the action / to tear up the newspaper/. Both verbs here mean "to tear up" and are those we expect with this action (even if they extend to other actions). For instance A-POL 5 used them both in tasks of denomination and reformulation respectively for the same action:

For the action / to tear up the newspaper/:

- Rozdziera (A-POL 5) "She tears up violently" (task of denomination)

- Nie wiem, rozrywa (A-POL 5) "I do not know, she tears up" (task of reformulation)

It is worth noting that rozrywać is composed of the verb rwać and the prefix roz. We expect it with this action and it means "to tear up" at the only condition that it is preceded by the prefix roz. Drzeć, even when used with different prefixes (prze or roz which gives the infinitive rozdzierać) which slightly affect its meaning, still means "to tear up".

We shall now study how generic verbs may be used in an unconventional way.

\subsection{GENERIC VERBS IN UNCONVENTIONAL USE}

In this section, we will present our results on unconventional statements including generic verbs. Our participants used generic verbs in both a conventional and an unconventional way. We are interested in the latter, which we will present here: generic verbs used with objects they do not apply to or with actions they do not suit. In a first language, such a verb seems more accessible than a specific verb because it is easier to acquire. 
Ex. 2 (roz)zbić, (z)tamać et (po)psuć "to break"

This example is a fine illustration of the frequent unconventional use of generic verbs by our participants. Participants of all ages used these verbs:

*Denomination tasks:

For the action / to burst a balloon/:

- Zbiła balon "She broke the balloon" (A-POL 3)

- Rozbija balon "She breaks the balloon" (A-POL 2)

- Ce qui m'est venu en premier n'est pas correct (in French), rozbiła balon "What occurred to me first is not right, she broke the balloon" (A-POL 1)

- Balon. Blanc (in French). Zbiła "Balloon. White. She broke" (LMP-EAP 1)

For the action / to mash tomato/:

- Zbita pomidor "She broke tomato" (LMP-EAP 1)

For the action / to tear up the newspaper/:

- Rozbiła gazete "She broke the newspaper" (LMP-EAT 6)

For the action / to crumble bread/:

- Rozbiła "She broke" (LMP-EAT 6)

For the action / to break bread/:

- Złamała chleb "She broke the bread" (LMP-EAT 4)

- Złamała bagietkę nierówno "She broke the baguette unevenly" (A-POL 4)

- Złamała bagietkę "She broke the baguette" (A-POL 10)

- Złamała "She broke" (LMP-EAT 6)

Three children used a verb meaning "to break" (po)psuć:

For the action / to tear up the newspaper/:

- Gazete. Popsuła i położyła "Newspaper. She broke and put down it" (LMP-EAP 1)

For the action / to unpick a shirt/:

- Koszulkę. Popsuła "The shirt. She broke it" (LMP-EAP 1) 
For the action / to break up bread/:

- Popsuła "She broke" (LMP-EAP 1)

For the action / to dismantle legos/:

- Coś muszi popsuć "She must break something"(LMP-EAP 2)

- Psuje wieże "She breaks a tower" (LMP-EAT 5)

*Reformulation tasks:

For the action / to burst a balloon/:

- Popsuła balon "She broke the balloon" (A-POL 11)

For the action / to mash tomato/:

- Rozbiła "She broke" (A-POL 11)

For the action / to break bread/:

- Złamała "She broke" (LMP-EAP 1)

For the action / to crumple paper/:

- Popsuła "She broke" (LMP-EAP 1)

In Polish, three verbs, (roz)zbić, (z)tamać and (po)psuć, can translate into "to break". They are synonymous but do not apply to the same objects or semantic fields. This illustrates how some Polish verbs are almost perfect synonyms and are translated in the same way.

- In the first place, three participants used the verb (roz)zbić, with or without the prefix roz which does not alter the meaning of the verb stem in that case. Zbić usually applies to solid objects such as glass and implies destruction. It is often linked to the fall of an object. It implies abruptness, which is also suggested by the balloon bursting suddenly. Nevertheless, a link appears between verbs: a burst balloon, a mashed tomato, a teared-up newspaper and a broken object. Consequences are identical since the object is destroyed in all cases. The notion of destruction links the expressed verb (roz)zbic "to break" to the conventional verbs.

As a result, (roz)zbic "to break" is an extra-field co-hyponym of przebic "to pierce", gnieść and miażdżyć "to mash" and rozdzierać "to tear up" (the expected verbs). They share the superordinate niszczyć "to damage".

Another link exists between (roz)zbić "to break" and kruszyć "to crumble". Here, it is the notion of division that unites the two verbs. (Roz)zbic "to break" implies that the object destroyed was fragmented into several pieces. Therefore, (roz)zbic "to break" is an extra-field co-hyponym 
of kruszyć "to crumble". They share the superordinate oddzielać "to separate".

We notice that zbić and przebić stem from the same radical bić, with varied prefixes which modify its meaning. With a radical other than prze, such as $z$ or roz, the verb is unconventional in the action / to burst balloon/. As discussed above, Polish prefixes can alter or modulate the meaning of a verb on their own.

- Secondly three participants gave the verb łamać with the prefix $z$ for the action / to break bread/.

This verb does not apply to an object which belongs to the category of food. It may be used for instance with a pen, a lace or toys. It implies that an object can no longer be used. (Z)łamać applies better to worn or broken objects but without any sense of abruptness. It also applies to limbs, such as legs. It is worth noting that łamać alone or with other prefixes would suit the action, tamać is the expected verb. It is the prefix $z$ that put it in a sphere of approximation. The two verbs, (z)tamać and tamać, share a notion of division, as a matter of fact, a broken object can be divided into several pieces. Therefore, (z)tamać "to break" and łamać "to break up" are extra-field co-hyponyms. They share the same superordinate oddzielać "to separate".

- Finally, three participants, all children in early acquisition, used the verb psuć. It does not apply to objects such as paper, bread, a tomato or a balloon. Instead, it applies to toys or cars, to mechanisms which deteriorate like that of a watch for instance. It also applies to human organs, as in psuć oczy "to strain one's eyes". At the same time, it is often used in the figurative, as in psuć sobie krew (literally "to wear out one's blood"), "to worry". It is the expression of an object or a situation resulting in a slow and long-lasting damage. Only children in early acquisition use the verb (po)psuć. It is a variant of "to break" which any adult may use. It is accessible to children and often used with objects such as "toys". However, adults may feel it is not appropriate. The prefix po does not affect the meaning of the verb.

(Roz)zbić, (z)łamać and (po)psuć are generic verbs. They may apply to several objects and situations. Such verbs are well-known because they refer to familiar situations and apply to numerous daily situations. Participants whatever their age know these verbs and use them because they can easily access them. For Bowermann (2007), to break is frequently over-extended in English and through this example we observe that it is 
also the case in Polish. For the author, children take a long time to learn which objects a verb applies to. She shows that in a study of Pye, only children use to break with paper, not adults. In our study too only a child uses that verb with newspaper. We shall now study another example:

Ex. 3. Otwierać "to open"

Three participants used that verb; one of them used it ten times.

*Denomination tasks:

For the action / to peel a banana/:

- Otwiera banan "She opens a banana" (LMP-EAP 5)

- Otwiera banana "She opens a banana" (LMP-EAT 2)

For the action / to peel an orange/:

- Otwiera pomarańcza "She opens an orange" (LMP-EAT 2)

- Otwiera coś "She opens something" (LMP-EAP 2)

For the action / to unpick a shirt/:

- Otwiera kurtke "She opens jacket" (LMP-EAT 2)

- Otwiera «klupki» (mot inexistant) jakiejś koszulki "She opens kulpki (this word does not exist) of a shirt" (LMP-EAP 2)

For the action / to cut (up) bread/:

- Otwiera chleb "She opens bread" (LMP-EAP 2)

For the action / to chop parsley/:

- Otwiera coś "She opens something" (LMP-EAP 2)

For the action / to undress a doll/:

- Laleczki coś otwiera "She opens something from the doll" (LMP-EAP 2)

For the action / to strip the bark off a $\log /$ :

- Otwiera drzewo jakieś "She opens a tree" (LMP-EAP 2)

For the action / to crumble bread/:

- Otwiera chleb "She opens bread" (LMP-EAP 2)

For the action /to peel a carrot/:

- Coś otwiera "She opens something" (LMP-EAP 2)

For the action / to break bread/:

- Otwiera chleb jakiś "She opens a bread" (LMP-EAP 2) 
For the action / to saw a plank/:

- Otwiera but "She opens the shoe" (LMP-EAP 2)

*Reformulation tasks:

For the action / to tear up the newspaper/:

- Otwiera gazete "She opens newspaper" (LMP-EAP 2)

For the action / to undress a doll/:

- Otwiera laleczkę żeby była goła "She opens doll in order to make her naked" (LMP-EAP 2)

For the action / to peel a banana/:

- Banan otwiera "Banana she opens" (LMP-EAP 2)

For the action / to peel an orange/:

- Pani otworzyła "The lady has open" (A-POL 4)

For the action / to unpick a shirt/:

- Otwiera "She opens" (LMP-EAT 5)

For the action / to strip the bark off a $\log /$ :

- Otwiera "She opens" (LMP-EAT 5)

Otwierać "to open" applies to several objects, such as a bottle or a door and to human organs, like the eyes. This verb applies to fruits and vegetables; as a result some approximations are intra-fields. Otwierać "to open" is an intra-field co-hyponym of obierać "to peel". They share the superordinate zdejmować "to take off".

In other approximations there is a gap between verb and objects.

Otwierać is an extra-field co-hyponym of siekać «to chop», łamać «to break up», pitować «to saw», kroić «to cut» and kruszyć «to crumble». They share the same superordinate oddzielać «to separate».

Otwierać is an extra-field co-hyponym of rozbierać «to undress». They share the same superordinate zdejmować «to take off».

Otwierać is an extra-field co-hyponym of obdzierać «to strip». They share the superordinate zdejmować «to take off».

The category niszczyć «détériorer» does not contain any action. The reason is that this verb shares the idea of division with expected verbs.

According to Bowermann (2007), to open is frequently used as an over-extension in English and we note that it is also the case in Polish. 
Ex. 4 rozbierać "to undress"

*Denomination tasks:

For the action /to strip the bark off a $\log /$ :

- Rozbiera drewno "She undresses the wood" (LMP-EAP 5)

For the action /to peel an orange/:

- Rozbiera mandarynkę "She undresses a mandarin" (LMP-EAP 4)

For the action /to peel a carrot/:

- Rozbierze marchewke "She will undress a carrot" (LMP-EAP 4)

*Reformulation tasks:

For the action /to peel an orange/:

- Rozbiera pomarańcze "She undresses the orange" (A-POL 3)

Rozbierać "to undress" usually applies to animated beings like humans or animals. It does not suit the category of objects such as fruits or wood. Its use is conventional with a doll, for the action /to undress a doll/ but it is unconventional with a carrot, wood or an orange. For the action /to undress a doll/ it indicates that clothes are taken off an animated being. The wood, the orange and the carrot do not wear clothes but have a skin which is assimilated to clothes. Moreover, some of the distinctive features of the verb conform to the actions. In this verb, we note the idea of taking away or removing, which we find in these actions. A parallel may be drawn between these situations: the skin of fruits/wood is seen in comparison with clothes which will be taken off. The verbs we expect and the situation awaiting description emphasize taking away or removing an external element. These precise characteristics of rozbierać "to undress" are taken into account and revealed in the choice of this verb. They gather the chosen verb and the expected verb. The participants compared two situations which they found to be similar and used the necessary lexicon from the source situation. The notions of taking away or removing are useful to connect the two situations. Our participants took into account these two concepts and overshadowed those which were useless to describe the action. Furthermore the verb rozbierać "to undress" is familiar and common. It belongs to everyday life, while the verb obdzierać "to bark" is not very usual and is used only in specific situations. The accessible lexicon supersedes the unknown lexicon when 
parallel situations are deemed similar. Otherwise, the verb predicts with accuracy the final situation: an external element removed from an object.

Rozbierać "to undress" is a co-hyponym extra-field of obdzierać "to bark" and obierać "to peel". They share the same superordinate zdejmować "to take off".

\section{CONCLUSION AND DISCUSSION}

Our work revealed and studied two elements linked with verbal acquisition in Polish as a first language. The first one is the role of generic verbs, such as psuć "to break" which may be used in a conventional or unconventional way. The second one is unconventional statements such as Rozbiera pomarańcze "She undresses the orange", which cell can be a generic verb. We showed that children, especially during the phase of early acquisition, but also children with a more developed lexicon and adults make unconventional statements which are mostly based on generic verbs.

Our results, both statistical and qualitative, reveal that every participant produced generic verbs and unconventional statements. During the acquisition of a first language, generic verbs are acquired before any other verb (Viberg, 2002), (Noyau, $2005 ; 2008$ ) and (Bernicot, 1981). As a matter of fact, during early acquisition, children mostly produce unconventional statements and they also use a large amount of generic verbs for their restricted lexicon. Generic verbs are still present in the adult lexicon, adults use common and accessible verbs in order to fill or vary their lexicon. Children in the phase of early acquisition, children with a more developed lexicon and adults resort to generic verbs in approximate use.

The very common use of generic verbs in Polish suggests that all participants used this type of verb with great ease. Every participant used these common, standard and familiar verbs which apply to many objects and situations. This means that adults with a stable knowledge of Polish, children in early acquisition and children with a more mature lexicon all commonly use these verbs. Generic and superordinate verbs are broadly used and may be a palliative strategy. Participants know these verbs very well and use them often; they may be used instead of less-known specific verbs. Approximations based on this kind of verbs allowed subjects to provide a coherent answer to the test. It may have been unusual but it 
was nonetheless a significant and comprehensible answer. They expressed the meaning of the action without using the conventional verb.

We note that approximations matter in acquiring and structuring the verbal lexicon, where they serve as palliative strategies. Every participant in our study made verb-based approximations. This proves that cognitive flexibility is at work among numerous age populations. It allows them to face different problems due to their lack of lexicon. Indeed, both children in the process of acquiring their lexicon and adults use approximations as strategies. Moreover, all participants used them to bypass the usual code and communicate in a coherent way. Such statements and generic verbs are essential and allow people to overcome difficulties in accessing the lexicon.

We propose an organization by co-hyponyms for the Polish verbal lexicon. We have shown that this proposal suits the Polish language. The verbs choosen would thus be co-hyponyms of the verbs we expect. For instance obierać "to peel" is unconventional in the action / to strip the bark off a $\log /$. But this verb would be the co-hyponym of obdzierać "to bark". They would share the same superordinate zdejmować "to take off".

In this study, we have discussed our results on approximations with generic verbs. We could not present results on unconventional statements with specific verbs because all Polish approximations are based on generic verbs.

We postulate a great number of generic verbs and unconventional statements in French as foreign language.

\section{BIBLIOGRAPHY}

BERNICOT J. (1981) Le développement des systèmes sémantiques de verbes d'action, Editions du Centre National de la Recherche Scientifique, Paris.

CLARK E. V. (2003) First language acquisition, Cambridge University Press.

DUVIGNAU K. (2003) Métaphore verbale et approximation, Revue d'Intelligence Artificielle, Paris, Vol 5/6: 869-881.

DUVIGNAU K., GARDES-TAMINE J. et GAUME B. (2004) Approximations sémantiques enfantines et distance inter-verbes: pour une organisation proxémique du lexique verbal, Le langage et l'homme, De Boeck, Vol 39-2: 123-141, Belgique.

DUVIGNAU K., GAUME B. et NESPOULOUS J.-L. (2004) Proximité sémantique et stratégies palliatives chez le jeune enfant et l'aphasique, Parole, numéro spécial, J.-L. Nespoulos \& J. Virbel (Coord.): «Handicap langagier et recherches cognitives: apports mutuels», UMH, Vol 31-32: 219-255, Belgique. 
DUVIGNAU K. (2005) Pour un apprentissage-enseignement du lexique verbal calqué sur l'acquisition: revisite et apport des «métaphores//erreurs» des enfants de 2-4 ans, In GROSSMANN F., PAVEAU M.-A., PETIT G., eds. Apprentissage du lexique: langue, cognition, discours, ELLUG: 37-49, Grenoble.

JANOWSKA A. i PASTUCHWA M. (2005) Słowotwórstwo czasowników staropolskich, TAiWPN Universitas.

LAFONT R. (1978) Le travail et la langue, Flammarion, Paris.

MAJID A., BOWERMAN M., VAN STADEN M. and BOSTER J. S. (2007) The semantic categories of cutting and breaking events: A crosslinguistic perspective. Cognitive Linguistics, 18(2), 133-152.

MOLINO J. (1979) La métaphore, Didier-Larousse, Paris.

NOYAU C. (2008) Place des verbes dans le Français Fondamental, acquisition $\mathrm{du}$ lexique verbal en français langue seconde, et didactique du lexique in Bouchard R. et Cortier C. Pratiques et représentations de l'oral en FLES, 50 ans après le français fondamental. Le français dans le Monde-Recherches et applications, $\mathrm{n}^{\circ}$ spécial, p. 87-101.

VIBERG A. (2002) Basic verbs in Second Language Acquisition, Revue Française de Linguistique Applquée 2002/2, Vol VII: 61-79.

WINNER E. (1978) New names for old things: the emergence of metaphoric language, Journal of child Language Vol 6: 469-491, Cambridge university press.

Słownik synonimów i antonimów, 2004, Europa wydawnictwo, Wrocław.

\section{KONSTRUKCJE CZASOWNIKOWE W NAUCE JĘZYKA OJCZYSTEGO - PROCES PRZYSWAJANIA SYSTEMU SEMANTYCZNEGO CZASOWNIKA}

\section{Streszczenie}

Celem artykułu jest analiza wybranych elementów procesu akwizycji języka polskiego jako ojczystego. Jednym z nich jest hierarchia leksykalna czasowników. Ucząc się języka ojczystego, dzieci często używają czasowników generycznych, takich jak kroić, (roz)zbić, (z)łamać, po(psuć), w zastępstwie czasowników o bardziej wyspecjalizowanym znaczeniu, co skutkuje tworzeniem wielu wyrażeń niekonwencjonalnych. Innym analizowanym zagadnieniem są niekonwencjonalne konstrukcje powstałe na zasadzie rozszerzenia semantycznego lub mające charakter metafor. Konstrukcje tego typu często uważane za błędy, jednak wydaje się, że można je także uznać za przejaw elastyczności semantycznej, niezbędnej $\mathrm{w}$ procesie przyswajania systemu czasownika w języku ojczystym. Leksyka czasownikowa zbudowana jest na zasadzie podobieństw znaczeniowych, co zostało przekonująco udokumentowane przez innych badaczy.

Badanie zostało przeprowadzone na grupie osób dorosłych i dzieci reprezentujących różne poziomy kompetencji językowej. Ich zadaniem było nazwanie 
pewnych czynności oraz podanie nazw o podobnym znaczeniu. Wyniki poddano analizie semantycznej i statystycznej, która ujawniła tendencję do użycia czasowników generycznych i konstrukcji niekonwencjonalnych wśród wszystkich uczestników eksperymentu.

Słowa kluczowe: czasownik, akwizycja języka, język polski, semantyczny, generyczny, metafora.

\section{VERB-BASED APPROXIMATIONS IN POLISH AS A FIRST LANGUAGE: ACQUIRING AND STRUCTURING THE VERBAL LEXICON}

\section{Summary}

We want to study two elements involved in the acquisition of Polish as a first language.

The first element is lexical hierarchy of verbs. We observe that, when acquiring the verbal lexicon of a first language, learners use a large number of generic verbs such as kroić "to cut" or (roz)zbić, (z)łamać et (po)psuć "to break". These verbs may be used in non conventional statements.

The second element is non conventional statements based on verbs, such as Rozbiera drewno "She undresses the wood". These statements are considered as errors, over-extensions or metaphors. But we assert that these statements reflect a semantic flexibility which is essential to the acquisition of the (verbal) lexicon when learning a first language. We believe that verbal lexicon is organized through semantic proximity. This is in agreement with several other authors' works.

Our subjects are Polish adults and children. The children may be in the early or late stages of language acquisition.

They were subjected to an experimental protocol which consisted in two tasks: action denomination and action reformulation. Our results include both semantic and statistical analysis. They reveal that all types of subjects produce a large number of generic verbs and non conventional statements.

Key words: verbs, acquisition, Polish, semantic, approximation, generic, metaphor. 